\title{
10. LITERATURVERZEICHNIS
}

\subsection{Sekundärliteratur}

ABBASI, Muhammad Y., Leadership of London Muslim League. Analysis of the Tussle between Mohamed Ali Johar and Syed Ameer Ali, in: Journal of the Pakistan Historical Society 32 (1984) S. 1-12.

-, London Muslim League 1908-1928. An Historical Study, Islamabad 1988 (Historical Studies Muslim India Series, 8).

Abd el-Krim et la Republique du Rif. Actes du colloque international d'études historiques et sociologiques, 18-20 janvier 1973, Paris 1976.

ABDELlaOUI, Mohamed el, CHIKHI, Nour E., Explotación de los recursos naturales, in: NoGUE, Villanova (Hg.), España, S. 509-550.

ABRAMSON, Rudy, Spanning the Century. The Life of W. Averell Harriman 1891-1986, New York 1992.

ABUN-NASR, Jamil M., The Salafiyya Movement in Morocco. The Religious Bases of the Moroccan Nationalist Movement, in: St. Anthony Papers 16 (1963) S. 90-105.

-, A History of the Maghrib, Cambridge u.a. ${ }^{2} 1975$.

AGERON, Charles R., Les socialistes français et la Guerre du Rif, in: Abd el-Krim et la République du Rif, S. 273-292.

-, La presse parisienne devant la Guerre du Rif (avril 1925-mai 1926), in: Revue de l'occident musulman et de la méditerranée 24 (1977) S. 7-27.

AHMED, Mesbahuddin, The British Labour Party and the Indian Independence Movement 1917-1939, London 1987.

AlAOUI, Moulay A., Le Maroc du traité de Fès à la libération 1912-1956, Rabat 1994.

-, Le Maroc face aux convoitises européennes 1831-1912, Salé 2001.

ALBERT, Pierre, La presse française de 1871 à 1940, in: Claude BELLANGER, Jacques GodECHOT, Pierre GUIRAL (Hg.), Histoire générale de la presse française, Bd. 3: De 1871 à 1940, Paris 1972, S. 135-622.

ALBóNICO, Aldo, L'Italia el il mondo iberico nel primo dopoguerra. Velletia coloniali ed economiche 1919-1923, in: Nuovo rivista storica 66 (1982) S. 82-132.

AllaIN, Jean-Claude, Agadir 1911. Une crise impérialiste en Europe pour la conquête du Maroc, Paris 1976.

Álvarez, José E., The Betrothed of Death. The Spanish Foreign Legion during the Rif Rebellion 1920-1927. Florida State University (Diss.) 1995.

-, Tank Warfare during the Rif Rebellion 1921-1927, in: Armor, Januar-Februar 1997, S. 26-28.

-, Between Gallipoli and D-Day. Alhucemas 1925, in: Journal of Military History 63 (1999) S. 75-98.

-, The Betrothed of Death. The Spanish Foreign Legion during the Rif Rebellion 1920 1927, Westport 2001 (Contributions in Comparative Colonial Studies, 40).

AMSON, Daniel, Poincaré. L'acharné de la politique, Paris 1997.

ANDERSON, Roy C., Devils, Not Men. The History of the French Foreign Legion, London 1987.

ASPREY, Robert B., War in the Shadows. The Guerilla in History, New York 1994.

ATKIN, Nicholas, Pétain, London 1998. 
Auswahlbibliographie. Publikationen zu Marokko ab Erscheinungsjahr 1980, in: Wuqûf 4-5 (1989-1990) S. 465-485.

AYACHE, Germain, Les implications internationales de la Guerre du Rif 1921-1926, in: Hespéris-Tamuda 15 (1974) S. 181-224.

-, Société rifaine et pouvoir central marocain 1850-1920, in: Revue historique 254 (1975) S. 345-370.

- (Hg.), Études d'histoire marocaine, Rabat 1979.

-, La première amitié germano-marocaine 1885-1894, in: DERS. (Hg.), Études, S. 229-247.

-, La crise des relations germano-marocaines 1894-1897, in: DERS. (Hg.), Études, S. 249 291.

-, Les origines de la Guerre du Rif, Paris, Rabat 1981.

-, Les relations franco-espagnoles pendant la Guerre du Rif, in: Españoles y Franceses en la primera mitad del siglo XX, hg. vom Centro de estudios historicos, Madrid 1986, S. 287293.

-, La Guerre du Rif, Paris u.a. 1996.

AYOUBI, Mohamed el, Les merveilles du Rif, Contes berbères narrés par Fatima n Mubehrur, Utrecht 2000.

AzIZ, Khursheed K., Ameer Ali. His Life and Work, Lahore 1968.

AZZZA, Mimoun, Le Rif sous le protectorat espagnol 1912-1956. Marginalisation et changements sociaux. Naissance du salariat, Paris (Diss.) 1994.

AZZOU, El-Mostafa, Les relations franco-américaines en Maroc entre 1906 et 1956, Paris (Diss.) 1992.

-, L'escadrille Lafayette: Des aviateurs américains dans la Guerre du Rif 1921-1926, in: Guerres mondiales et conflits contemporains 53 (2003) S. 57-63.

BAÎ̃A, Jamaâ, La presse marocaine d'expression française. Des origines à 1956, Rabat 1996.

BAILEY, Ronald, Anglo-Moroccan Relations to 1900. A Short History, in: Maghreb Review 16 (1991) S. 200-239.

BAKER, Alison, Voices of Resistance. OTal Histories of Moroccan Women, Albany 1998.

Balfour, Sebastian, Preston, Paul (Hg.), Spain and the Great Powers in the Twentieth Century, London 1999.

,,-- Introduction. Spain and the Great Powers, in: DIES. (Hg.), Spain, S. 1-12.

-, LA PORTE, Pablo, Spanish Military Cultures and the Moroccan Wars 1909-1936, in: European History Quarterly 30 (2000) S. 307-332.

-, Deadly Embrace. Morocco and the Road to the Spanish Civil War, Oxford 2002.

BARBEY, Frédéric, Un homme d'état suisse. Gustave Ador 1845-1928, Genf 1945.

BARTHEL, Günter, STOCK, Kristina (Hg.), Lexikon Arabische Welt. Kultur, Lebensweise, Wirtschaft, Politik und Natur im Nahen Osten und Nordafrika, Wiesbaden 1994.

BAUM, Die Eisenerzlagerstätten Nordwestafrikas, in: Stahl und Eisen 23 (1903) S. 713-726.

BEN ASSAR, Y., Der Kampf um das Schatzland. Er Rif, ein Industriezentrum von morgen, Berlin 1926.

BenewiCK, Robert, Political Violence and Public Order. A Study of British Fascism, London 1969.

BENJELLOUN, Abdelmajid, >Pacification` de la zone d'influence espagnole au Maroc septentrional 1909-1927, in: Revue d'histoire maghrebine 33-34 (1984) S. 13-38.

BENNETT, George H., Britain's Relations with France after Versailles. The Problem of Tangier 1919-1923, in: European History Quarterly 24 (1994) S. 53-84.

-, British Foreign Policy during the Curzon Period 1919-1924, London 1995.

BENOIST-MECHIN, Jacques, Lyautey l'Africain ou le rêve immolé 1854-1934, Paris 1978 (Le rêve le plus long de l'histoire, 6). 
BERMAN, Nathaniel, »The Appeals of the Orient«. Colonized Desire and the War of the Riff, in: Karen KNOP (Hg.), Gender and Human Rights, Oxford 2004 (The Collected Courses of the Academy of European Law, 12, 2), S. 195-230.

BERMAN, Nina, Impossible Missions? German Economic, Military and Humanitarian Efforts in Africa, Lincoln 2004.

BESSIS, Juliette, Chekib Arslan et les mouvements nationalistes au Maghreb, in: Revue historique 259 (1978) S. 467-489.

BIDWELl, Robin, Morocco under Colonial Rule. French Administration of Tribal Areas 1912-1956, London 1973.

-, BIDWELL, Margaret, Morocco. The Traveller's Companion, London, New York 1992.

BIONDI, Jean-Pierre, Les anti-colonialistes 1881-1962, Paris 1992.

BITTERLI, Urs, Die ,Wilden ( und die ,Zivilisierten<. Grundzïge einer Geistes- und Kulturgeschichte der europäisch-überseeischen Begegnung, München 1976.

BLOND, Georges, Histoire de la Légion étrangère 1831-1981, Paris 1981.

BLÜMNER, Oberst, Die »Heldentaten« der französischen Fremdenlegion in Marokko, in: Deutsches Offiziersblatt 30 (1926), H. 5, S. 36f.

BoDE, John, Abd el Krim's Freiheitskampf gegen Franzosen und Spanier, Charlottenburg 1926.

BOERSNER, Demetrio, The Bolsheviks and the National and Colonial Question 1917-1928, Genf 1957 (Etudes d'histoire économique, politique et sociale, 20).

BORGE, Jacques, VIASNOFF, Nicolas, Archives au Maroc, Paris 1995.

BosQue COMA, Alfredo, Prisionero de Abd el-Krim, in: Historia 1616 (1992) S. 23-28.

BOUAZIZ, Mostafa, Le mouvement national marocain 1912-1975. Permanences et tentatives de renouvellement, Paris (Diss.) 1987.

BoUHASSOUN, Baghdad, La pénétration espagnole dans le Rif 1909-1921, Toulouse (Diss.) 1989.

BOURGET, Pierre, La rivalité Pétain-Lyautey de 1925 au Maroc. Un nouvel éclairage, in: Guerres mondiales et conflits contemporains 46 (1996) S. 125-133.

BOUTBOUQALT, Tayeb, La politique d'information du protectorat français au Maroc 19121956, Paris (Diss.) 1986.

-, La Guerre du Rif et la réaction de l'opinion internationale 1921-1926, Casablanca 1992.

BOYD, Carolyn P., Praetorian Politics in Liberal Spain, Chapel Hill 1979.

BRANDT-MaNNeSMaNN, Ruth, Max Mannesmann, Reinhard Mannesmann. Dokumente aus dem Leben der Erfinder, Remscheid 1964.

BRETT, Michael, Don Roberto and the Tourmaline Affair. British Filibusters in the Canaries and Southern Morocco 1875-1900, in: Victor MORALEs LezCANO (Hg.), Il Aula Canarias y el Noroeste de Africa, Las Palmas de Gran Canaria 1988, S. 413-421.

-, On the Historical Links between Morocco and Europe, in: George Joffe (Hg.), Morocco and Europe, London 1989, S. 5-12.

BRIEDEN, Hubert, Giftgasbomben für Spanisch-Marokko. Deutschlands Beteiligung am ersten vaero-chemischen« Krieg, in: Junge Welt, 17.7.1998.

BRÖCKLING, Ulrich, SIKORA, Michael, Einleitung, in: DIES. (Hg.), Die Armeen und ihre Deserteure. Vernachlässigte Kapitel einer Militärgeschichte der Neuzeit, Göttingen 1998, S. 7-15.

BroUÉ, Pierre, Histoire de l'Internationale communiste 1919-1943, Paris 1997.

BROWN, Kenneth, Résistance et nationalisme, in: Abd el-Krim et la République du Rif, S. 472-477.

BRUMLIK, Micha, Das Jahrhundert der Extreme, in: WOJAK, MENL (Hg.), Völkermord, S. $19-36$.

BRUNET, Jean-Paul, Jacques Doriot. Du communisme au fascisme, Paris 1986.

BRUNON, Jean, Lyautey aux confins algéro-marocains, in: Cahiers Charles de Foucauld 42 (1954) S. 105-119. 
BruSSAC, Philippe, La Légion étrangère, Paris 1955 (Les grandes réussites françaises, 4).

BuEno y NUÑEZ DE PADRo, Emilio, Historía de la acción de España en Marruecos desde 1904 a 1927, Madrid 1929.

Bugnion, François, Le Comité international de la Croix-Rouge et la protection des victimes de la guerte, Genf 1994.

BUISSERET, Alexandre, Les femmes et l'automobile a la Belle époque, in: Le mouvement social 192 (2000) S. 41-64.

BURKE, Edmund, Pan-Islam and Moroccan Resistance to French Colonial Penetration 1900 1912, in: Journal of African History 13 (1972) S. 97-118.

-, Moroccan Resistance, Pan-Islam and German War Strategy 1914-1918, in: Francia 3 (1975) S. 434-464.

-, Prelude to Protectorate in Morocco. Precolonial Protest and Resistance 1860-1912, Chicago 1976.

BUSSEY, Gertrude C., TIMS, Margaret, Women's International League for Peace and Freedom 1915-1965. A Record of Fifty Years' Work, London 1965.

CallaghaN, John, Rajani Palme Dutt. A Study in British Stalinism, London 1993.

CAMBON, Henri, Histoire du Maroc, Paris 1952.

CAMPOS MARTINeZ, José M., Abd-el-Krim y el Protectorado, Malaga 2000 (Colección Africa propia, 18).

CARRASCo GaRcía, Antonio, Notas sobre el desastre de Annual, in: Estudios africanos 10 (1996) S. 155-170.

-, MeSA GUTírReZ, José L. de, DOMínGUEZ LlOSÁ, Santiago L., Alhucemas 1925. Las imágenes del desembarco, Madrid 2000.

-, MUÑOZ BOLAÑoS, Roberto (Hg.), Las campañas de Marruecos 1909-1927, Madrid 2001.

CASSARA, Catherine, Edgar Ansel Mowrer and Paul Scott Mowrer, in: GARRATY, CARNES (Hg.), American National Biography, Bd. 16, S. $42-44$.

Cenival, Pierre de, FunCK-Brentano, Christian, Boussier, Marcel, Bibliographie marocaine 1923-1933, Paris 1937.

CHANDLER, James A., Spain and her Moroccan Protectorate 1898-1927, in: Journal of Contemporary History 10 (1975) S. 301-322.

-, The Responsibilities for Annual, in: Iberian Studies 6 (1977) S. 68-77.

CHARNAY, Jean-Paul, Technique et géosociologie. La Guerre du Rif. Le nucléaire en Orient, Paris 1984 (Travaux du centre d'études et de recherches sur les stratégies et les conflits, Série contemporaine, 4).

CHARQI, Mimoun, My. Mohamed Abdelkrim El Khattabi. L'émir guerillero, Rabat 2003.

CHARVIN, Robert, Le parti communiste français face à la Guerre du Rif, in: Abd el-Krim et la Republique du Rif, S. 218-236.

Chavrebiere, Coissac de, Histoire du Maroc, Paris 1931.

ChTATOU, Mohamed, Bin Abd al-Karim al-Khattabi in the Rif Oral Tradition of Gzenneya, in: JOFFÉ, PENNELL (Hg.), Tribe and State, S. 182-212.

-, Aspectos de la organización política en el Rif durante el reinado de Ben Abdel-Krim ElKhattabi, in: Fundamentos de antropologia 4-5 (1996) S. 61-70.

ClaRK, Peter, Marmaduke Pickthall. British Muslim, London u.a. 1986.

ClAYTON, Anthony, France, Soldiers and Africa, London u.a. 1988.

CLÉMENT, Jean-François, Nationale Geschichtsschreibung der zeitgenössischen marokkanischen Historiker, in: Wuqûf 4-5 (1989-1990) S. 383-399.

ClERISSE, Henry, La soumission du Rif, in: L'Illustration 84 (1926) S. 594f.

-, La Guerre du Rif et la Tache du Taza 1925-1926, Paris 1929.

Cochrane, A., Charles Wallace Alexander Napier Ross Cochrane-Baillie, Second Baron Lamington 1860-1940, in: Leopold G.W. LEGG (Hg.), The Dictionary of National Biography, Bd. 4: 1931-1940, London 1949, S. 30f. 
Connaughton, Richard M., The Republic of the Ushakovka. Admiral Kolchak and the Allied Intervention in Siberia 1918-1920, London, New York 1990.

COOK, Chris, Sources in British Political History 1900-1951, Bde. 3-4, London 1977.

COON, Carleton S., Tribes of the Rif, Cambridge 1931.

-, Flesh of the Wild Ox. A Riffian Chronicle of High Valleys and Long Rifles, New York 1932.

-, The Riffian, London 1934.

-, Adventures and Discoveries. The Autobiography of Carleton S. Coon, Englewood Cliffs 1981.

COURTOIS, Stéphane, LAZAR, Marc, Histoire du Parti communiste français, Paris 1995.

CREMADEILLS, Jacques, Le Parti communiste français et le Maroc 1920-1938, 2 Bde., Toulouse (Diss.) 1975.

Cross, Colin, The Fascists in Britain, London 1961.

CROzIER, Andrew J., Die Kolonialfrage während der Locarno-Verhandlungen und danach. Ein Essay über die Beziehungen zwischen Großbritannien und Deutschland 1924-1927, in: Wolfgang MichaLKA, Marshall M. LEE (Hg.), Gustav Stresemann, Darmstadt 1982 (Wege der Forschung, 539), S. 324-349.

CROzIER, Brian, Franco. A Biographical History, London 1967.

CrUZ SeOANe, María, SÁlZ, María D., Historia del periodismo en España, Bd. 3: El siglo XX 1898-1936, Madrid 1996.

Cullen, Maurice R., Paul Scott Mowrer, in: Perry J. Ashley (Hg.), American Newspaper Journalists 1926-1950, Detroit 1984 (Dictionary of Literary Biography, 29), S. 256-261.

DAIX, Pierre, Aragon. Une vie à changer, Paris 1975.

DAOUD, Zakya, Abdelkrim. Une épopée d'or et de sang, Paris 1999.

DEL BOCA, Angelo, Faschismus und Kolonialismus. Der Mythos von den »anständigen Italienern«, in: WOJAK, MEINL (Hg.), Völkermord, S. 193-202.

DESMOND, Robert W., Crisis and Conflict. World News Reporting between Two Wars 1920-1940, lowa City 1980.

Devos, Jean-Claude, CORVISIER-DE VILlELE, Marie-Anne, Guide des archives et sources complémentaires du SHAT, Vincennes 1996.

DíaZ MORLÁN, Pablo, Capital minero e industrialización. El grupo empresarial vizcaíno »Echevarrieta y Larrinaga« 1882-1916, in: Revista de historia industrial 9 (1996) S. 153173.

-, Horacio Echevarrieta 1870-1963. El capitalista republicano, Madrid 1999.

-, Un ejemplo de clientelismo empresarial. La influencia politica del industrial Horacio Echevarrieta, in: Historia social 36 (2000) S. 101-120.

DíaZ NOSTY, Bernardo, La irresistible ascensión de Juan March. Notas previas para una investigación biográfia, Madrid 1977.

DIECKMANN, Walter, Die geologischen Verhältnisse der Umgebung von Melilla unter besonderer Berücksichtigung der Eisenerz-Lagerstätten des Gebietes von Beni-Bu-Ifrur im marokkanischen Rif, Berlin (Diss.) 1912.

DIETRICH, Yorck, Die Mannesmannröhren-Werke 1888-1920. Organisation und Unternehmensführung unter der Gründerfamilie, Bankiers und Managern, Stuttgart 1991 (Zeitschrift für Unternehmensgeschichte, Beiheft, 66).

DRIESSEN, Henk, Images of Spanish Colonialism in the Rif. An Essay in Historical Anthropology and Photography, in: Critique of Anthropology 7 (1987) S. 53-66.

-, On the Spanish-Moroccan Frontier. A Study in Ritual, Power and Ethnicity, New York, Oxford 1992.

DUMAS, Pierre, Abd-el-Krim, Toulouse 1927.

DUNET, A.V., La sanglante aventure marocaine, Paris 1926. 
DunN, Ross E., Bu Himara's European Connexion. The Commercial Relations of a Moroccan Warlord, in: Journal of African History 21 (1980) S. 235-253.

-, France, Spain and the Bu Himara Rebellion, in: JOFFÉ, PENNELl (Hg.), Tribe and State, S. 145-158.

DuRAND, André, Histoire du Comité international de la Croix-Rouge, Bd. 2: De Sarajevo à Hiroshima, Genf 1978.

DuRAND, Roger, Barbey, Daniel, CandauX, Jean-Daniel (Hg.), Gustave Ador. 58 ans d'engagement politique et humanitaire. Actes du colloque Gustave Ador tenu au palais de l'Aténée les 9, 10 et 11 novembre 1995, Genf 1996.

ELORZA, Antonio, BIZCARRONDO, Marta, Queridos camaradas. La Internacional comunista y España 1919-1939, Barcelona 1999.

ENDRES, Franz C., Die Pazifisten, in: Das Tagebuch 6 (1925) S. 1401-1403.

ESCHE, Jan, Koloniales Anspruchsdenken in Deutschland im Ersten Weltkrieg, während der Versailler Friedensverhandlungen und in der Weimarer Republik (1914 bis 1933), Hamburg (Diss.) 1989.

ESPAÑA, Juan de, La actuación de España en Marruecos, Madrid 1926.

EVEREST-PHILLIPS, Max, The Suburban King of Tartary, in: Asian Affairs 21 (1990) S. 324 335.

FAATH, Ute, Das Bild Marokkos in der deutschen Fremdenlegionärsliteratur, in: POPP (Hg.), Die Sicht des Anderen, S. 85-89.

FASI, Allal al, The Independence Movements in Arab North Africa, New York 1970 (Near Eastern Translation Program, 8).

FAUVET, Jacques, Histoire du Parti communiste français de 1920 à 1976, Paris 1977.

FINDLAY, Anne M., FINDLAY, Allan M., Morocco, Oxford ${ }^{2} 1995$ (World Bibliographical Series, 47).

FISCHER, Otto, Wermelskirchen. Die Stadt von über 1000 Jahren und seine Industrie, Wermelskirchen 1926.

FITZGerald, S.V., Syed Ameer Ali 1849-1928, in: John R.H. WeAVER (Hg.), The Dictionary of National Biography 1922-1930, Oxford 1937, S. 18f.

FITZHERBERT, Margaret, The Man Who Was Greenmantle. A Biography of Aubrey Herbert, London 1983.

FLEMING, Peter, The Fate of Admiral Kolchak, London 1963.

FLEMING, Shannon E., El problema español de Marruecos y el desembarco en Alhucemas, in: Revista de historia militar 35 (1973) S. 155-172.

-, Primo de Rivera and Spain's Moroccan Problem 1923-1927, in: Journal of Contemporary History 12 (1977) S. 85-99.

-, North Africa and the Middle East, in: James W. CORTADA (Hg.), Spain in the TwentiethCentury World. Essays on Spanish Diplomacy 1898-1978, London 1980 (Contributions in Political Science, 30), S. 121-154.

-, Primo de Rivera and Abd-el-Krim. The Struggle in Spanish Morocco 1923-1927, New York, London 1991.

-, Spanish Morocco and the Second Republic. Consistency in Colonial Policy, in: Mediterranean Historical Review 13 (1998) S. 80-99.

FLournoy, Francis R., British Policy towards Morocco in the Age of Palmerston 18301865, Westport 1970 (Nachdr. d. Ausg. London 1935).

FONTAINE, Pierre, L'étrange aventure riffaine, Paris 1943.

-, Abd el-Krim. Origine de la rebellion nord-africaine, Paris 1958.

FORSTMANN, Walter, Die Mannesmänner in Marokko, in: Deutsche Bergwerkszeitung, 19.12.1936. 
FRAUENHOLZ, Eugen von, Der spanische Krieg in Marokko, in: Wissen und Wehr 8 (1927) S. 100-114.

FREMEAUX, Jacques, La France et l'Islam depuis 1789, Paris 1991.

FRUNSE, Michail W., Die europäischen Zivilisatoren und Marokko, in: DERS. (Hg.), Ausgewählte Schriften, Berlin 1956, S. 47-543.

FURNEAUX, Rupert, Abdel Krim. Emir of the Rif, London 1967.

Gallissot, René, Le parti communiste et la Guerre du Rif, in: Abd el-Krim et la République du Rif, S. 237-261.

GANIAGE, Jean, Histoire contemporaine du Maghreb. De 1830 à nos jours, Paris 1994.

GARRATT, Geoffrey T., Gibraltar and the Mediterranean, London 1939.

GaRRATY, John A., CARNES, Mark C. (Hg.), American National Biography, Bd. 16, New York 1999.

GAUCHER, Roland, Histoire secrète du parti communiste français 1920-1974, Paris 1974.

GAUDIO, Attilio, Guerres et paix au Maroc. Reportages 1950-1990, Paris 1991.

GeraGHTY, Tony, La Légion. »Marche ou crève«, Paris 1988.

GERSHOVICH, Moshe, French Military Rule in Morocco. Colonialism and its Consequences, London, Portland 2000 (History and Society in the Islamic World, 1).

GHEBALI, Victor-Yves und Catherine, Répertoire des séries de documents de la Société des Nations 1919-1947, 2 Bde., Dobbs Ferry 1973.

GHIRELL, Angelo, Monografia de la kabila de Bokoia, in: Archivo del Instituto de estudios africanos de Madrid 8 (1955) S. 27-83.

GIL GRIMAU, Rodolfo, Aproximación a una bibliografia española sobre el norte de Africa 1850-1980, Madrid 1982.

GLLERT, Martin, Geschichte des 20. Jahrhunderts, Bd. 2: 1919-1933, München 1998.

GIORGI-MIGNOT, Béatrice, Les milieux politiques français et les groupes de pression face à la guerre du Rif 1924-1927, Poitiers (Diss.) 1983.

GLEICHEN, Edward, France, Spain and the Rif. By Walter Harris (Rezension), in: Journal of the Royal Institute of International Affairs 6 (1927) S. 260.

GODCHOT, C., Le mystère des mines du Rif, in: Revue mondiale 174 (1926) S. 247-254.

GOLDBERG, G., Marokkos Eisenerze in ihrer wirtschaftlichen Bedeutung zu Deutschland, in:

Zeitschrift für Kolonialpolitik, Kolonialrecht und Kolonialwirtschaft 14 (1912) S. 29-35.

GómEZ APARICIO, Pedro, Historia del periodismo español, Bd. 3: De las guerras coloniales a la dictadura, Madrid 1974.

GrAF, Otto, Abd el Krims »Freiheitskampf«. Eine kolonialpolitische Studie, in: Die Tat 21 (1929-1930) S. 298-305.

-, Die marokkanische Mauer, Berlin 1933.

GRAVES, Richard P., Richard Hughes. A Biography, London 1994.

GRIFFITHS, Richard, Patriotism Perverted. Captain Ramsay, the Right Club and British AntiSemitism 1939-1940, London 1998.

GroEHLER, Olaf, Der lautlose Tod. Einsatz und Entwicklung deutscher Giftgase von 1914 bis 1945, Reinbek 1989.

GroHMANN-KEROUACH, Brigitte, Der Siedlungsraum der Ait Ouriaghel im östlichen Rif. Kulturgeographie eines Rückzugsgebietes, Heidelberg 1971 (Heidelberger geographische Arbeiten, 35).

GRŬNDER, Horst, Geschichte der deutschen Kolonien, Paderborn u.a. ${ }^{4} 2000$.

GruPP, Peter, Die Haltung des »Bulletin du Comité de l'Afrique française« gegenüber Deutschland von 1891 bis 1914, in: Francia 3 (1975) S. 393-433.

GuILlEN, Pierre, MIEGE, Jean-Louis, Les débuts de la politique allemande au Maroc 1870 1877, in: Revue historique 234 (1965) S. 323-352.

-, L'Allemagne et le Maroc 1870-1905, Paris 1967. 
-, Les questions coloniales dans les relations franco-allemandes à la veille de la première guerre mondiale, in: Revue historique 248 (1972) S. 87-106.

-, Aux origines de l'internationalisation de Tanger. Les négociations sur le statut international 1912-1924, in: Abdelouahed BENDAOUD, Mohammed MANIAR (Hg.), Tanger 18001956. Contribution à l'histoire récente du Maroc, Rabat 1991, S. 205-215.

GUTIERREZ DE LA PAZ, José A., La explotación de mineral de hierro en el Rif, in: De economía 16 (1951) S. 428-446.

HADHRI, Mohieddine, Nationalisme et anti-imperialisme. La place du Maghreb dans la stratégie soviétique au cours des années vingts, in: Cahiers de Tunisie 29 (1981) S. 307-334.

-, L'URSS et le Maghreb. De la révolution d'octobre à l'indépendance de l'Algèrie 19171962, Paris 1985.

HAESSNER, Max, Marokkos Handelsbeziehungen seit 1905 mit besonderer Berücksichtigung von Deutschland, Berlin 1912.

HAIKAL, Mustafa, Für eine Internationale der Völker. Zur Tätigkeit arabischer Antikolonialisten in der »Liga gegen Imperialismus und für nationale Unabhängigkeit火, in: Asien, Afrika, Lateinamerika 18 (1990) S. 846-856.

-, Das Internationale Kolonialbüro der Komintern in Paris, in: Jahrbuch für historische Kommunismusforschung 1 (1993) S. 126-130.

HALL, Luella J., The United States and Morocco 1776-1956, Metuchen 1971.

HALLGARTEN, George W. F., Imperialismus vor 1914. Die soziologischen Grundlagen der Außenpolitik europäischer Großmächte vor dem Ersten Weltkrieg, 2 Bde., München ${ }^{2} 1963$.

HaRLow, Alvin F., Herbert Myrick, in: Dumas MaLONE (Hg.), Dictionary of American Biography, Bd. 13, London, New York 1934, S. 376f.

HAROUCHI, Abderrahim, Les États-Unis face à la République du Rif, in: Abd el-Krim et la République du Rif, S. 367-373.

HARRINGTON, Peter, The Great War's Human Plight, in: MHQ, The Quarterly Journal of Military History 13 (2000) S. 48-53.

HART, David M., Notes on the Riffian Community of Tangier, in: The Middle East Journal 11 (1957) S. 135-169.

-, The Aith Waryaghar of the Moroccan Rif. An Ethnography and History, Tucson 1976 (Viking Fund Publications in Anthropology, 55).

-, Tribe and Society in Rural Morocco, London u.a. 2000.

-, The Saint and the Schoolmaster, or Jbala Warlord and Rifian Reformer Revisited. Conflicting Views of Islam in a Confrontation and Power Clash in Colonial Northern Morocco 1924-25, in: Journal of North African Studies 6 (2001) S. 29-60.

HartmanN, Peter C., Pariser Archive, Bibliotheken und Dokumentationszentren zur Geschichte des 19. und 20. Jahrhunderts. Eine Einführung in Benützungspraxis und Bestände für Historiker, Politologen und Journalisten, München 1976 (Dokumentation Westeuropa, 1).

HaSLAM, Beryl, From Suffrage to Internationalism. The Political Evolution of Three British Feminists 1908-1939, New York u.a. 1999 (American University Studies, Ser. 9: History, 168).

HATZFELD, Lutz, Mannesmann, in: Neue Deutsche Biographie, Bd. 16, Berlin 1990, S. 6164.

HEALD, Morrell, Transatlantic Vistas. American Journalists in Europe 1900-1940, Kent, London 1988.

HEDIN, Sven, Die Straße von Gibraltar, in: Stettiner General-Anzeiger, 9.12.1925.

-, Hinter den Kulissen des Marokkokrieges. Der Kampf um die Straße von Gibraltar, in: Neue Freie Presse, 22.12.1925.

-, Die Schuld am Kriege in Marokko, in: Neue Freie Presse, 10.1.1926. 
HENRICH, Lothar A., Die Schlacht von Anoual vor achtzig Jahren, in: Junge Welt, 21.7.2001.

Hernández Herrera, Carlos, García Figueras, Tomás, Acción de España en Marruecos, 2 Bde., Madrid 1929.

HERNÁNDEZ MIR, Francisco, Del desastre a la victoria 1921-1926, 4 Bde., Madrid 19261927.

HeSS, Jean, Une Algérie nouvelle. Quelques principes de colonisation pratique sur le propos du Maroc oriental et de Port-Say, Paris 1909.

HILLS, George, Franco. The Man and his Nation, London 1967.

-, Rock of Contention. A History of Gibraltar, London 1974.

HoCHSCHILD, Adam, Schatten über dem Kongo. Die Geschichte eines fast vergessenen Menschheitsverbrechens, Reinbek 2002.

HoDGSON, Johan, Edith Durham, Traveller and Publicist, in: John B. ALLCOCK, Antonia YouNG (Hg.), Black Lambs and Grey Falcons. Women Travellers in the Balkans, Bradford 1991, S. 8-34.

HOISINGTON, William A., Lyautey and the French Conquest of Morocco, New York 1995.

HOLTON, Sandra, The Suffragist and the »Average Woman«, in: Women's History Review 1 (1992), S. 9-24.

HöPP, Gerhard, Die arabischen Nationalrevolutionäre in Berlin und die Liga, in: Hans PIAZZA (Red.), Die Liga gegen Imperialismus und für nationale Unabhängigkeit 1927-1937. Zur Geschichte und Aktualität einer wenig bekannten antikolonialen Weltorganisation. Protokoll einer wissenschaftlichen Konferenz am 9. und 10. Februar 1987 an der KarlMarx-Universităt Leipzig, Leipzig 1987, S. 105-112.

$\rightarrow$, Zwischen Moschee und Demonstration. Muslime in Berlin 1922-1930, in: Moslemische Revue 10 (1990) S. 135-146, S. 230-238, 11 (1991) S. 13-19.

-, Die Schuldigkeit der Mohren. Muslimische Deserteure im Deutschland der Zwischenkriegszeit 1919-1926, in: Études germano-africaines 15-16 (1997-1998) S. 192-202.

-, Frontenwechsel. Muslimische Deserteure im Ersten und Zweiten Weltkrieg und in der Zwischenkriegszeit, in: DeRS., Brigitte REINwALD (Hg.), Fremdeinsätze. Afrikaner und Asiaten in europäischen Kriegen 1914-1945, Berlin 2000 (Zentrum Moderner Orient, Geisteswissenschaftliche Zentren Berlin e.V., Studien, 13), S. 129-141.

HORNUNG, Peter, Die Legion. Europas letzte Söldner, München 1981.

Howell, David, British Workers and the Independent Labour Party 1888-1906, Manchester 1983.

HUETZ DE LEMPS, Xavier, La collaboration franco-espagnol pendant la Guerre du Rif 19251927. Un mariage d'amour ou de raison, in: Hesperis-Tamuda 29 (1991) S. 85-111.

IHRAI-AOUCHAR, Amina, La presse nationaliste et le régime du protectorat au Maroc dans l'entre-deux-guerres, in: Revue de l'occident musulman et de la méditerranée 34 (1982) S. 91-104.

ISOART, Paul, La Guerre du Rif et le parlement français, in: Abd el-Krim et la Republique du Rif, S. 173-208.

JACQUES, Hubert, Nos ennemis au Maroc, in: Journal, 1.6.1925.

-, L'aventure riffaine et ses dessous politiques, Paris 1927.

JAMOUS, Raymond, Honneur et baraka. Les structures sociales traditionelles dans le Rif, Cambridge, Paris 1981.

JEDERMANN, La »bolchévisation« du Parti communiste français, Paris 1971.

JENSEN, Robert G., José Millán-Astray and the Nationalist sCrusader in Spain, in: Journal of Contemporary History 27 (1992) S. 425-447.

JoffÉ, George, PENNELl, Charles R. (Hg.), Tribe and State. Essays in Honour of David Montgomery Hart, Wisbech 1991. 
-, Walter Harris and the Imperial Vision of Morocco, in: Journal of North African Studies 1 (1996) S. 248-265.

JOVER ZAMORA, José M. (Hg.), La España de Alfonso XIII. El estado y la política 19021931, Bd. 2: Del plano inclinado hacia la dictadura al final de la monarquía 1922-1931, Madrid 1995 (Historia de España, Menéndez Pidal, 38).

JULIEN, Charles-André, Le Maroc face aux impérialismes 1415-1956, Paris 1978.

JÜRKE, Erhard, Vision und Realpolitik. Die Britische Independent Labour Party im Lernprozeß 1893-1914, Frankfurt a. M. 1988 (Moralische Ökonomie, 3).

KADDACHE, Mahfoud, Histoire du nationalisme algérien. Question nationale et politique algérienne 1919-1951, Algier 1980.

KAINBACHER, Paul, Die Erforschung Afrikas, Bd. 2: Die Afrika-Literatur über Geographie und Reisen vor 1945, Nachtrag: 1800-1914, Teil 3: 1915-1945, Baden 1999.

KAMINSKL, Hanns-Erich, Spanisch-Marokko, in: Weltbühne 20 (1924) S. 718-720.

KEIGER, John F. V., Raymond Poincaré. Cambridge u.a. 1997.

KENBIB, Mohammed, The Impact of the French Conquest of Algeria on Morocco 1830 1912, in: Hespéris-Tamuda 29 (1991) S. 47-60.

-, Juifs et musulmans au Maroc 1859-1948. Contribution à l'histoire des relations intercommunautaires en terre d'Islam, Rabat 1994.

KENT, George O. (Hg.), Catalogue of Files and Microfilms of the German Foreign Ministry Archives 1920-1945, 4 Bde., Stanford 1962-1972.

KerILlIS, Henri de, A Prisoner of the Moors, in: The Living Age 317 (1923) S. 398-401.

KHAN, Ali A., Ameer Ali's Services to Turkey, in: Journal of the Asiatic Society of Bangladesh 22 (1977) S. 54-65

KHARCHICH, Mohammed, La France et la Guerre du Rif 1921-1926, Lyon (Diss.) 1989.

-, Les négotiations franco-rifaines 1924-1926. Un processus lent et illusoire, in: Revue d'histoire maghrebine 18 (1991) S. 295-313.

-, Observations sur les causes de l'échec du mouvement rifain, in: Revue d'histoire maghrébine 21 (1994) S. 219-235.

-, La alianza franco-española contra el movimiento rifeño, in: Fundamentos de antropología 4-5 (1996) S. 71-89.

-, Left Wing Politics in Lyon and the Rif War, in: Journal of North African Studies 2 (1997) S. $34-45$.

KLEIN-WINTERMANN, E., Bodenschätze im Rif und in Marokko, in: Die Umschau 29 (1925) S. 865-868.

-, Mohamed Abd el-Krim ben Ghattabi. Eine geschichtsphilosophische Studie, in: Zeitschrift für Geopolitik 3 (1926) S. 493-508.

KoCH, Heinrich, 75 Jahre Mannesmann. Geschichte einer Erfindung und eines Unternehmens 1890-1965, Düsseldorf 1965.

KGRNER, Francis, La Guerre du Rif espagnole vue par la Direction des affaires indigènes française 1912-1924, in: Revue historique 287 (1992) S. 141-156.

KOLLER, Christian, "Von Wilden aller Rassen niedergemetzelt«. Die Diskussion um die Verwendung von Kolonialtruppen in Europa zwischen Rassismus, Kolonial- und Militärpolitik 1914-1930, Stuttgart 2001 (Beiträge zur Kolonial- und Überseegeschichte, 82).

KöSE, Ali, Conversion to Islam. A Study of Native British Converts, London, New York 1996.

KOULAKSSIS, Ahmed, MEYNIER, Gilbert, L'émir Khaled, premier za'im? Identité algérienne et colonialisme français, Paris 1987.

KRATOCHWIL, Gabriele, Die Berberbewegung in Marokko. Zur Geschichte der Konstruktion einer ethnischen Identität 1912-1997, Berlin 2002 (Islamkundliche Untersuchungen, 247). 
KUNZ, Rudibert , MŬLlER, Rolf-Dieter, Giftgas gegen Abd el Krim. Deutschland, Spanien und der Giftgaskrieg in Spanisch-Marokko 1922-1927, Freiburg i. Br. 1990 (Einzelschriften zur Militärgeschichte, 34).

-, "Con ayuda del más dañino de todos los gases«. Der Gaskrieg gegen die Rif-Kabylen in Spanisch-Marokko 1922-1927, in: WOJAK, MENL (Hg.), Völkermord, S. 153-191.

LA PORTE, Pablo, El desastre de Anual. Un olvido historiographico, in: Cuadernos de historia contemporánea 19 (1997) S. 223-229.

-, From Cuba to Annual. Spain's Colonial Policy in Morocco and the Crisis of the Liberal System 1898-1923, in: International Journal of Iberian Studies 13 (2000) S. 14-24.

-, La atracción del imán. El desastre de Annual y sus repercusiones en la política europea 1921-1923, Madrid 2001.

LABONNE, Roger, L'Islam et la révolte riffaine, in: Correspondant 300 (1925) S. 801-827.

LADREIT DE LACHARRIERE, Jacques, Les amis d'Abd el Krim, in: Le Temps, 31.12.1925.

-, Le rêve d'Abd el Kerim. Esquisse d'histoire marocaine, Paris 1925.

-, Abd el Krim, agent et profiteur du bolchévisme, in: Revue des sciences politiques 40 (1925) S. 435-450.

-, Intrigues riffaines, in: Revue indigène 203-204 (1925) S. 232-236.

-, Les origines et les conséquences du soulèvement rifain, in: Revue hebdomadaire 34 (1925) S. 91-103, S. 223-237.

-, La Tache de Taza et l'action militaire de la France au Maroc, in: Revue des sciences politiques 49 (1926) S. 336-351, S. 486-512.

LAFFIN, John, The French Foreign Legion, London 1974.

LANDAU, Jacob M., The Politics of Pan-Islam. Ideology and Organization, Oxford 1994.

LANDAU, Rom, Portrait of Tangier, London 1952.

-, Moroccan Drama, 1900-1955, London 1956.

LANG, Hubert, Die Darstellung Abd el-Krims in der zeitgenössischen Publizistik, in: PopP (Hg.), Die Sicht des Anderen, S. 65-69.

LAROUI-BENJELLOUN, Latifa, Les bibliothèques au Maroc, Paris 1990.

LAREDO, Abraham I., Les noms des Juifs du Maroc. Essai d'onomastique judéo-marocaine, Madrid 1978 (Consejo superior de investigaciones cientificas, Instituto de Filologia, E, 3).

LAYBOURN, Keith, Recent Writing on the History of the ILP 1893-1932, in: DERS., David JAMES, Tony JowITT (Hg.), The Centennial History of the Independent Labour Party. A Collection of Essays, Halifax 1992, S. 317-336.

LAZAARE, Khalid, Marokko in deutschen Reiseberichten des 19. und beginnenden 20. Jahrhunderts. Vorstudien zur deutschen Wahmehmung einer islamischen Region, Frankfurt a. M. 1998 (Studien zur neueren Literatur, 7).

LÁzaro AVILA, Carlos, La forja de la aeronáutica militar, Marruecos, in: CARRASCo GarCíA, MuÑoz Bolaños (Hg.), Las campañas, S. 164-193.

LE GUENNEC, Nicole, Le parti communiste français et la Guerre du Rif, in: Le mouvement social 78-81 (1972) S. 39-64.

LE GuilLERME, Marc, CH. »402«. $2^{e}$ bureau marocain. Histoire vécue au Rif $1925-1926$, Paris 1935.

Le TOURneaU, Roger, Histoire du Maroc moderne, Aix-en-Provence 1992.

LEBzELTER, Gisela, Die »Schwarze Schmach«. Vorurteile, Propaganda, Mythos, in: Geschichte und Gesellschaft 11 (1985) S. 37-58.

LEGUINECHE, Manuel, Annual. El desastre de España en el Rif 1921, Madrid 1996.

LEONIDOFF, Der Kampf um die Eisenerze Nordafrikas, in: Wirtschaftsdienst 13 (1928) S. $1971-1974$.

LEVAINVILLE, Jacques, Les minerais de fer dans la zone espagnole au Maroc, in: La géographie 35 (1921) S. 169f.

LILIENTHAL, Erich, Giftgas in Marokko, in: Tägliche Rundschau, 5.6.1925. 
LITTLE, Douglas J., Twenty Years of Turmoil. ITT, the State Department, and Spain 1924 1944, in: Business History Review 53 (1979) S. 449-472.

LLABADOR, Francis, Port-Say et son fondateur Louis Jean-Baptiste Say, lieutenant de vaisseau de réserve 1852-1915, Oran 1955.

LOPEZ RIENDA, Rafael, Abd-el-Krim contra Francia. Impresiones de un cronista de guerra, Madrid 1925.

LOUTSKAİA, Nathalie, À propos de la structure intérieure de la République du Rif, Moskau 1960.

LOZE, Pierre, Tanger, repaire de bandits, citadelle des contrebandiers, in: Petit Journal, 6.4.1926.

-, Chez eux qui ravitaillent les rebelles riffaines, in: Petit Journal, 12.4.1926.

-, L'état-major d'Abd el Krim, in: Petit Journal, 14.4.1926.

LŪSEBRNK, Hans-Jürgen, Die marokkanischen Kolonialsoldaten (Tirailleurs) in Deutschland 1919-1923. Präsenz, Wahrnehmungsformen, Konflikte, in: POPP (Hg.), Die Sicht des Anderen, S. 53-64.

MAC ORLAN, Pierte, La Légion étrangère, Paris 1933.

MCKERCHER, Brian J., »A Dose of Fascismo«. Esme Howard in Spain 1919-1924, in: International History Review 9 (1987) S. 555-585.

-, Esme Howard. A Diplomatic Biography, Cambridge u.a. 1989.

MCLEAVE, Hugh, The Damned Die Hard. The Story of the French Foreign Legion, Farnborough 1974.

MCMEEKIN, Sean, From Moscow to Vichy. Three Working-Class Militants and the French Communist Party 1920-1940, in: Contemporary European History 9 (2000) S. 1-38.

Madariaga, Maria-Rosa de, Le Parti socialiste espagnol et le Parti communiste d'Espagne face à la révolte rifaine, in: Abd el-Krim et la République du Rif, S. 308-366.

-, L'Espagne et le Rif. Pénétration coloniale et résistances locales 1909-1926, 2 Bde., Paris (Diss.) 1987.

-, Mohammed ben Abdelkrim el Jatabi y las ambivalencias del sprogresor, in: Fundamentos de antropología 4-5 (1996) S. 14-32.

-, Nacionalismos vasco y catalán frente a la revolución de Abd-el-Krim, in: Historia 1623 (1998) S. 69-77.

-, Estudio introductorio, in: OTEYZA, Abd-el-Krim, S. 11-52.

-, España y el Rif. Crónica de una historía casi olvidada, Melilla ${ }^{2} 2000$ (La biblioteca de Melilla, 12).

MAGHRAOUI, Driss, Moroccan Colonial Soldiers. Between Selective Memory and Collective Memory, in: Arab Studies Quarterly 20 (1998) S. 21-41.

MAITLAND, Alexander, Robert and Gabriela Cunninghame Graham, Edinburgh 1983.

MannesmanN, Claus H., Die Unternehmungen der Brūder Mannesmann in Marokko, Würzburg (Diss.) 1931.

MANUE, Georges R., Sur les marches du Maroc insoumis, Paris ${ }^{6} 1930$.

-, La fin d'un aventurier. Le légionnaire déserteur Klems, qui fut chef d'état-major du rebelle marocain Abd el Krim, vogue actuellement vers le bagne de la Guyane, in: Dépêche coloniale et maritime, 21.2.1930.

MARIN ARCE, José M., El gobierno de la concentración liberal. El rescate de prisioneros en poder de Abd-el-Krim, in: Revista de la Facultad de geografia e historia 1 (1987) S. 163181.

-, Primo de Rivera y la República del Rif durante los primeros años de la dictadura. Negociaciones con Abd-el-Krim en junio de 1925, in: RIPOLL PERELLó, LADERO QUESADA (Hg.), Actas, S. 271-286.

MARSAN, Étienne, L'ambassadeur d'Abd el Krim, in: Revue indigène 203-204 (1925) S. 236-239. 
MARTR CORRALES, Eloy, El protectorado español en Marruecos 1912-1956. Una perspectiva histórica, in: NOGUÉ, VILLANOVA (Hg.), España, S. 143-158.

MARTNETZ, Dieter, Vom Giftpfeil zum Chemiewaffenverbot. Zur Geschichte der chemischen Kampfmittel, Thun, Frankfurt a. M. 1995.

MASCHKE, Erich, Es entsteht ein Konzern. Paul Reusch und die GHH, Tübingen 1969.

MATEO DIESTE, Josep L., La whermandad« hispano-marroquí. Política y religión bajo el Protectorado español en Marruecos 1912-1956, Barcelona 2003.

MathEWS, Joseph J., Walter Burton Harris, Times Correspondent in Morocco, in: Journalism Quarterly 17 (1940) S. 227-231.

MATTES, Hanspeter, Das Bild Marokkos in der deutschsprachigen Reiseliteratur der Zwischenkriegszeit 1918-1939 und des zweiten Weltkriegs, in: Wuquf 4-5 (1989-1990) S. 343-358.

MatTIOLl, Aram, Entgrenzte Kriegsgewalt. Der italienische Giftgaseinsatz in Abessinien 1935-1936, in: Vierteljahreshefte für Zeitgeschichte 51 (2003) S. 311-337.

-, Die vergessenen Kolonialverbrechen des faschistischen Italien in Libyen 1923-1933, in: WOJAK, MEINL (Hg.), Völkermord, S. 203-226.

MAYER, Martin, Geheime Diplomatie und öffentliche Meinung. Die Parlamente in Frankreich, Deutschland und Großbritannien und die erste Marokkokrise 1904-1906, Düsseldorf 2002 (Beiträge zur Geschichte des Parlamentarismus und der politischen Parteien, 133).

MEAKER, Gerald H., The Revolutionary Left in Spain 1914-1923, Stanford 1974.

MELLOR, Francis H., Morocco Awakes, London 1939.

MERCER, Charles, Legion of Strangers. The Vivid History of an Unique Military Tradition The Foreign Legion, London u.a. 1964.

MESA GUTIERREZ, José L. de, 1919-1927, casi una década de sangre, in: CARRASCo GARCIA, MuÑoz Bolaños (Hg.), Las campañas, S. 128-163.

MEYER, Thomas, »Endlich eine Tat, eine befreiende Tat...«. Alfred von Kiderlen-Waechters "Panthersprung nach Agadir« unter dem Druck der öffentlichen Meinung, Husum 1996 (Historische Studien, 448).

MICHELS, Eckard, Deutsche in der Fremdenlegion 1870-1965. Mythen und Realitäten, Paderborn u.a. ${ }^{3} 2000$ (Krieg in der Geschichte, 2).

MiĖGE, Jean-Louis, Le Maroc et l'Europe 1830-1894, Bd. 4: Vers la Crise, Paris 1963.

-, L'arrière-plan diplomatique de la Guerre du Rif, in: Revue de l'occident musulman et de la méditerranée 15-16 (1973) S. 219-230.

-, Introduction historique. Les relations internationales, in: Abd el-Krim et la République du Rif, S. 25-32.

-, Abd el-Krim, in: Encyclopédie berbère, Bd. 1, Aix-en-Provence 1984, S. 73-76.

-, Le fonds du protectorat aux archives de Rabat, in: Monde et cultures 59-60 (1999-2000) S. 68-82.

MIERKA, Alfred von, Die militärische Lage in Marokko I. Die Kämpfe bei Wessan und Taza, in: Kölnische Zeitung, 11.9.1925.

-, Die militärische Lage in Marokko II. Die Kämpfe am Werga, nördlich von Taza und in der spanischen Zone bis Mitte September, in: Kölnische Zeitung, 25.9.1925.

-, Die militärische Lage in Marokko III. Die Kämpfe von Mitte September bis zur Einnahme von Aschdir, in: Kölnische Zeitung, 10.1925.

-, Die militärische Lage in Marokko IV. Die Einschließung des Rifgebiets im Osten, in: Kölnische Zeitung, 23.10.1925.

-, Die militärische Lage in Marokko V. Umgruppierung und Verteidigungslinie, in: Kölnische Zeitung, 27.11.1925.

-, Die militärische Lage in Marokko. Neue Kämpfe zu erwarten, in: Kölnische Zeitung, 26.3.1926. 
-, Der letzte Akt des marokkanischen Feldzugs. Die große spanisch-marokkanische Offensive, in: Kölnische Zeitung, 16.6.1926.

-, Die Kämpfe und die Friedensfrage in Marokko, in: Militärwissenschaftliche und Technische Mitteilungen 57 (1926) S. 265-276.

-, Spanier und Franzosen nach Abd el Krims Fall, in: Militärwissenschaftliche und Technische Mitteilungen 57 (1926) S. 689-694.

MiLES, Alexander, Devil's Island. Colony of the Damned, Berkeley 1988.

MiQUel, Pietre, Poincaré, Paris 1984.

MIRANTI, Paul J., Herbert Myrick, in: GaRRATY, CARNES (Hg.), American National Biography, Bd. 16, S. 209 f.

MOHR, Paul, Tragödie des Rif, in: Tägliche Rundschau, 8.9.1925.

-, Frankreichs wahre Marokkoziele, in: Tägliche Rundschau, 3.10.1925.

-, Abd el-Krim und der Marokkofriede, in: Tägliche Rundschau, 15.4.1926.

-, Frankreich und Marokko, Berlin 1926.

MOMMSEN, Wolfgang J., Das Zeitalter des Imperialismus, Frankfurt a. M. 1969 (Fischer Weltgeschichte, 28).

MONTAGNE, Robert, Abd el Krim, in: Politique étrangère 3 (1947) S. 301-324.

-, Révolution au Maroc, Paris 1953.

MONTAGNON, Pierre, Histoire de la Légion de 1931 à nos jours, Paris 1999.

MONTEIL, Vincent, La guerre révolutionnaire, in: Abd el-Krim et la République du Rif, S. $149-152$.

MONTJOU, Guy de, La Guerre du Rif, in: Revue de Paris 32 (1925) S. 574-601.

MONTORO OBRERO, Guadelupe, Tráfico de armas en la guerra de Marruecos 1907-1927, in: RIPOLl PEREllo, LADERo Quesada (Hg.), Actas, S. 245-259.

MORALES LEZCANO, Víctor, Las minas del Rif y el capital financiero peninsular 1906-1930, in: Moneda y crédito 135 (1975) S. 61-79.

-, El colonialismo hispanofrancés en Marruecos 1898-1927, Madrid 1976.

MORRIS, Andrew J. A., Radicalism against War 1906-1914. The Advocacy of Peace and Retrenchment, London 1972.

MORTIMER, Edward, The Rise of the French Communist Party 1920-1947, London, Boston 1984.

MOSCATl, Ruggero, La politica estera fascista nel '24-25, in: Rivista storica italiana 71 (1959) S. 313-320.

MOULIÈRAS, Auguste, Le Maroc inconnu. Étude géographique et sociologique, Bd. 1: Exploration du Rif, Paris 1895.

Munammad, Shan, The Right Honourable Syed Ameer Ali. Personality and Achievements, Neu-Dehli 1991.

MŪLLER, Herbert L., Islam, gihâd (»Heiliger Krieg») und Deutsches Reich. Ein Nachspiel zur wilhelminischen Weltpolitik im Maghreb 1914-1918, Frankfurt a. M. 1991 (Europäische Hochschulschriften, Reihe 3, Geschichte und ihre Hilfswissenschaften, 506).

MUNSON, Henry, The Mountain-People of Northwestern Morocco. Tribesmen or Peasants, in: Middle Eastern Studies 17 (1981) S. 249-255.

NaANA, Abdallah, Quand les gaz toxiques arrosaient le Rif, in: La vie économique, 28.7.3.8.2000.

NADEAU, Maurice, Geschichte des Surrealismus, Reinbek 1997.

NEARING, Scott, Stopping a War. The Fight of French Workers against the Moroccan Campaign of 1925, New York 1926.

NELSON, Keith L., The »Black Horror on the Rhine«. Race as a Factor in Post-World War I Diplomacy, in: Journal of Modern History 42 (1970) S. 606-627.

NIEMEIJER, Albert C., The Khilafat Movement in India 1919-1924, 's-Gravenhage 1972. 
NIMSCHOWSKI, Helmut, Grundzüge des antikolonialen Widerstandes in Marokko, in: Autorenkollektiv unter der Leitung von Lothar RATHMANN (Hg.), Geschichte der Araber. Von den Anfängen bis zur Gegenwart, Bd. 4: Die arabische Befreiungsbewegung im Kampf gegen die imperialistische Kolonialherrschaft 1917-1945, Berlin 1974, S. 259-294.

-, Das Eindringen in Marokko 1871-1898, in: STOECKER (Hg.), Drang nach Afrika, S. 113120.

NoGUÉ, Joan, VillaNoVA, José L. (Hg.), España en Marruecos 1912-1956. Discursos geográficos e intervención territorial, Lleida 1999.

-, -; La zona norte del Protectorado Español en Marruecos. El marco geográfico, in: DiES. (Hg.), España, S. 101-141.

NOUSCHI, André, La France et le pétrole. De 1924 à nos jours, Paris 2001.

ONCKEN, Emily, Panthersprung nach Agadir. Die deutsche Politik während der zweiten Marokkokrise 1911, Düsseldorf 1981.

OSSIETZKY, Carl von, Abd el Krim, Rif und Riffe, in: Weltbühne 22 (1926) S. 833-837.

OSTERHAMMEL, Jürgen, Transnationale Gesellschaftsgeschichte. Erweiterung oder Alternative, in: Geschichte und Gesellschaft 27 (2001) S. 464-479.

OVED, Georges, La gauche française et le nationalisme marocain 1905-1955, 2 Bde., Paris 1984.

-, La contribution des services spéciaux à la politique de la France au Maroc de 1920 à 1955 , in: Claude JOURNÈs (Hg.), Police et politique, Lyon 1988, S. 69-99.

PANDO, Juan, Historia secreta de Annual, Madrid 1999.

PARK, Thomas K., Historical Dictionary of Morocco, Lanham 1996 (African Historical Dictionaries, 71).

PARKER, John, Inside the Foreign Legion. The Sensational Story of the World's Toughest Army, London 1998.

PARSONS, Frederick V., The Origins of the Morocco Question 1880-1900, London 1976.

PATEL, Kiran K., Überlegungen zu einer transnationalen Geschichte, in: Zeitschrift für Geschichtswissenschaft 52 (2004) S. 626-645.

-, Nach der Nationalfixiertheit. Perspektiven einer transnationalen Geschichte, Berlin 2004 (Öffentliche Vorlesungen der Humboldt-Universität zu Berlin, 128).

PAYNE, Stanley G., Politics and the Military in Modern Spain, Stanford 1967.

PENNELL, Charles R., Law, Order and the Formation of an Islamic Residence to European Colonialism. The Rif 1921-1926, in: Revue d'histoire maghrébine 21 (1981) S. 25-39.

-, "I Wish to Live Peacefully in My Houser. A Moroccan Caid and his Reaction to Colonialism, in: Maghreb Review 6 (1981) S. 49-54.

-, The Responsibility for Anual. The Failure of Spanish Policy in the Spanish Protectorate 1912-1921, in: European Studies Review 12 (1982) S. 67-86.

-, A Country with a Government and a Flag. The Rif War in Morocco, Wisbech 1986.

-, Exito y fracaso de Abd-el-Krim, in: Historia 1611 (1986) S. 28-36.

-, Women and Resistance to Colonialism in Morocco. The Rif 1916-1926, in: Journal of African History 28 (1987) S. 107-118.

-, The Discovery of Morocco's Northern Coast, in: British Journal of Middle Eastern Studies 20 (1993) S. 226-236.

-, Dealing with Pirates. British, French and Moroccans 1834-56, in: Journal of Imperial and Commonwealth Studies 22 (1994) S. 54-83.

-, The Geography of Piracy. Northern Morocco in the Mid-Nineteenth Century, in: Journal of Historical Geography 20 (1994) S. 272-282.

-, The Rif War. Link or Cul-de-sac? Nationalism in the Cities and Resistance in the Mountains, in: Journal of North African Studies 1 (1996) S. 234-247.

-, Morocco since 1830. A History, London 2000. 
-, La guerra del Rif. Abdelkrim el-Jattabi y su estado rifeño, Melilla 2001 (La biblioteca de Melilla, 14).

-, Morocco. From Empire to Independence, Oxford 2003.

PESQUIÈS-COURBIER, Simone, L'aéronautique militaire française dans la Guerre du Rif, in: Revue du nord 285 (1990) S. 317-367.

PIERRE, Michel, La terre de la grande punition. Histoire des bagnes de Guyane, Paris 1982.

PLANHOL, Rene de, Skirting the Firing Line in Morocco, in: Living Age 325 (1925) S. 501505.

POGGE VON STRANDMANN, Hartmut, Rathenau, die Gebrüder Mannesmann und die Vorgeschichte der zweiten Marokkokrise, in: Imanuel GEISS, Bernd J. WENDT (Hg.), Deutschland in der Weltpolitik des 19. und 20. Jahrhunderts. Fritz Fischer zum 65. Geburtstag, Düsseldorf 1973, S. 251-270.

POHL, Heinrich, Marokko und Mannesmann. Ein völkerrechtlicher Rückblick, in: Zeitschrift für Politik 5 (1912) S. 558-577.

PolizzotT, Mark, Revolution des Geistes. Das Leben André Bretons, München, Wien 1996.

POLK, William R., The Education of a Nationalist. An Interview with Emir Abd el-Krim, in: Perspective of the Arab World. An Atlantic Monthly Supplement, New York 1956, S. 24 f.

POPP, Herbert (Hg.), Die Sicht des Anderen. Das Marokkobild der Deutschen, das Deutschlandbild der Marokkaner. Referate des 3. Deutsch-Marokkanischen Forschungs-Symposiums in Rabat, 10.-12. November 1993, Passau 1994 (Maghreb-Studien, 4).

PORCH, Douglas, The Conquest of Morocco, New York 1983.

-, The French Foreign Legion. A Complete History of the Legendary Fighting Force, New York 1991.

POSTHUMUS, Cyril, First Lady of Racing. The Remarkable Camille du Gast, in: Automobile Quarterly 14 (1976) S. 351-361.

POWELL, Edward A., In Barbary. Tunisia, Algeria, Morocco and the Sahara, New York, London 1926.

PRŌBSTER, Edgar, Vom marokkanischen Kriegsschauplatz, in: Deutsche Allgemeine Zeitung, 24.5.1925.

-, Die Minen des Rif, in: Deutsche Allgemeine Zeitung, 21.9.1925.

-, Der Krieg im Rif, in: Deutsche Allgemeine Zeitung, 3.10.1925.

-, Die Rifrepublik, in: Deutsche Allgemeine Zeitung, 22.10.1925.

-, Die Franzosen in Marokko, Berlin 1925.

-, Spanische Marokkozone und die Politik der Westmächte, in: Der Deutsche Gedanke 2 (1925) S. 360-366.

-, Das Rifproblem, in: Die Deutsche Nation 7 (1925) S. 401-406.

-, Liquidation der Rifrepublik, in: Der Deutsche Gedanke 3 (1926) S. 922-929.

-, Der Kampf um Marokko, in: Deutschlands Emeuerung 10 (1926) S. 170-178.

QURESHI, Muhammad N., Mohamed Ali's Khilafat Delegation to Europe (February-October 1920), Karachi 1980.

-, Pan-Islam in British Indian Politics. A Study of the Khilafat Movement 1918-1924, Leiden u.a. 1999 (Social, Economic, and Political Studies of the Middle East and Asia, 66).

RAHIM, Muhammad A., Syed Ameer Ali and the Muslim Renaissance Movement, Chittagong ${ }^{2} 1980$.

RANDERIA, Shalini, Geteilte Geschichte und verwobene Moderne, in: Jörn RÜSEN u.a. (Hg.), Zukunftsentwürfe. Ideen für eine Kultur der Veränderung, Frankfurt a. M. 1999, S. 87-96.

-. CONRAD, Sebastian, Einleitung. Geteilte Geschichten - Europa in einer postkolonialen Welt, in: DIES. (Hg.), Jenseits des Eurozentrismus. Postkoloniale Perspektiven in den Geschichts- und Kulturwissenschaften. Frankfurt a. M. 2002, S. 9-49. 
RATHMANN, Lothar, Araber stehen auf. Über den Befreiungskampf der arabischen Völker bis zum Ausbruch des zweiten Weltkrieges, Berlin 1960.

REDOUANE, Joëlle, La présence anglaise en Algérie de 1830 à 1930, in: Revue de l'occident musulman et de la méditerranné 38 (1984) S. 15-36.

REINDERS, Robert, Racialism on the Left. E.D. Morel and the »Black Horror on the Rhine«, in: International Review of Social History 13 (1968) S. 1-28.

RezZOUK, Ahmed, Notes sur l'organisation politique et administrative du Rif, in: Archives marocaines 5 (1905) S. 265-275.

RIESENBERGER, Dieter, Für Humanität im Krieg und Frieden. Das Internationale Rote Kreuz 1863-1977, Göttingen 1992.

RIOTTOT, Yveline, Joaquin Maurín. De l'anarcho-syndicalisme au communisme 1919-1936, Paris u.a. 1997.

RIPOll Perelló, Eduardo, Ladero Quesada, Manuel F. (Hg.), Actas del II Congreso internacional »El estrecho de Gibraltar«, Bd. 5: Historia contemporánea, Madrid 1995.

RITTER, Ernst, Quellen zur Geschichte Nordafrikas, Asiens und Ozeaniens in der Bundesrepublik Deutschland bis 1945, München u.a. 1984 (Quellenfuihrer zur Geschichte der Nationen, Reihe 3, Nordafrika, Asien und Ozeanien, 6).

RITTER, Gerhard A., Friedensbewegung in Großbritannien 1914-1918/19. Die Union of Democratic Control und ihr Kampf um eine gerechte Friedensordnung, in: Archiv für Sozialgeschichte 22 (1982) S. 403-471.

RIUDOR I GORGAS, Lluís, Expediciones, excursiones y correrias en el protectorado español en Marruecos, in: NoguÉ, Villanova (Hg.), Espatia, S. 303-339.

RIVET, Daniel, Le commandement français et ses réactions vis-d-vis du mouvement rifain 1924-1926, in: Abd el-Krim et la Republique du Rif, S. 101-136.

-, Mines et politique au Maroc 1907-1914, in: Revue d'histoire moderne et contemporaine 26 (1979) S. 549-578.

-, Lyautey et l'institution du protectorat français au Maroc 1912-1925, 3 Bde., Paris 1988.

-, Le Maroc de Lyautey à Mohammed V. Le double visage du protectorat, Paris 1999.

ROBRIEUX, Philippe, Maurice Thorez. Vie secrète et vie publique, Paris 1975.

RoCkwell, Paul Ayers, WalkeR, Dale L., Moroccan Bomber. American Fighters in the Rif War 1925, in: Aviation Quarterly 5 (1979) S. 108-135.

Rollin, Léon, La Commission arbitrale des litiges miniers au Maroc. Clôture des travaux, in: Bulletin du Comité de l'Afrique française 32 (1922) S. 302-304.

-, L'Espagne au Maroc et la question de Tanger, in: Bulletin du Comité de l'Afrique frangaise 34 (1924) S. 320-324.

-, L'Espagne au Maroc, in: Bulletin du Comité de l'Afrique française 35 (1925) S. 199-205, S. $659-663$.

-, Les mines du Rif, in: Bulletin du Comité de l'Afrique française 35 (1925) S. $455 f$.

-, L'Espagne au Maroc, in: Bulletin du Comité de l'Afrique française 36 (1926) S. 45-50.

RoTH, Mitchel P., Historical Dictionary of War Journalism, London 1997.

RūCHARDT, Benedikt, Deutsch-spanische Beziehungen 1898-1931, München (Diss.) 1988.

RũGER, Adolf, Richtlinien und Richtungen deutscher Kolonialpolitik 1923-1926, in: Peter HEINE, Ulrich VAN DER HEYDEN (Hg.), Studien zur Geschichte des deutschen Kolonialismus in Afrika. Festschrift zum 60. Geburtstag von Peter Sebald, Pfaffenweiler 1995, S. 453-465.

RUZÉ, Robert, Litiges minières du Maroc. L'affaire Mannesmann, in: Revue de droit international et de législation comparée 47 (1920) S. 159-168.

SAINT MARTIN, Monique de, L'espace de la noblesse, Paris 1993.

SAKLATVALA, Sehri, The Fifth Commandment. A Biography of Shapurji Saklatvala, Kalkutta 1996.

SALAFRANCA, Jesús F., La república del Rif, Malaga 2004. 
Salas larrazábal, Ramón, Protectorado de España en Marruecos, Madrid 1992 (Colección El Magreb, 3).

SÁNCHEZ PÉREZ, Andrés, Abdelkrim, in: Revista de historia militar 17 (1973) S. 123-157.

SÁNCHEZ VIGIL, Juan M., Alfonso, fotógrafo de un siglo, Madrid 1990.

SARMANT, Thierry (Red.), Guide des sources de l'histoire du Maroc au Service historique de l'armée de terre, Vincennes 2000.

SASSE, Dirk, Rezension zu Zakya Daoud, Abdelkrim. Une épopée d'or et de sang, Paris 1999, in: Francia 28, 3 (2001) S. 250f.

-, Spekulanten und Sympathisanten, Deserteure und Hasardeure. Abdelkrims Helfershelfer während des Rifkrieges 1921-1926, in: Jahrbuch für Europäische Überseegeschichte 4 (2004) S. 195-204.

SAZ, Ismael, Foreign Policy under the Dictatorship of Primo de Rivera, in: BALFOUR, PRESTON (Hg.), Spain, S. 53-72.

SCHMOECKEL, Gisela, Die maghrebinischen Abenteuer der Brüder Mannesmann, in: Bergischer Almanach 3 (1991) S. 7-19.

SCHULZE, Reinhard, Islamischer Internationalismus im 20. Jahrhundert. Untersuchungen zur Geschichte der islamischen Weltliga, Leiden u.a. 1990 (Social, Economic, and Political Studies of the Middle East, 41).

-, Geschichte der islamischen Welt im 20. Jahrhundert. München 1994.

SCHWEITZER, Sylvie, André Citroën. Pour une histoire du XXe siècle, Lyon 1992.

SCURR, John, The Spanish Foreign Legion, London 1985 (Men-at-Arms Series, 161).

SECo Serrano, Carlos, La España de Alfonso XIII. El estado y la política 1902-1931, Bd. 1: De los comienzos del reinado a los problemas de la posguerra 1902-1922, Madrid 1995 (Historia de España, Menéndez Pidal, 38).

-, El plano inclinado hacia la dictadura 1922-1923, in: JOVER ZAMORA (Hg.), La España, S. 11-130.

SÉmARD, Pierre, La Guetre du Rif, Paris 1926.

SEPASGOSARIAN, Ramin A., Eine ungetrübte Freundschaft? Deutschland und Spanien 19181933, Saarbrücken, Fort Lauderdale 1993 (Forschungen zu Spanien, 12).

SERELS, Mark M., A History of the Jews of Tangier in the Nineteenth and Twentieth Centuries, New York 1991.

ShaNAFElT, Gary W., An English Lady in High Albania. Edith Durham and the Balkans, in: East European Quarterly 30 (1996) S. 283-300

SHIN, Jae-Chang, La Guerre du Rif et la vie politique française, Lille (Diss.) 1977.

SHINAR, Pessah, Abd al-Qadir and Abd al-Krim. Religious Influences on their Thought and Action, in: Asian and African Studies 1 (1965) S. 139-174.

SICARD, Maurice-Ivan, Doriot et la Guerre du Rif. Études et documents, Paris 1943.

SIEVERS, Peter von, Nordafrika, in: Gustave E. von GrUNEBAUM (Hg.), Der Islam, Bd. 2:

Die islamischen Reiche nach dem Fall von Konstantinopel, Frankfurt a. M. 1971 (Fischer Weltgeschichte, 15), S. 392-437.

SIMPSON, Alfred W.B., In the Highest Degree Odious. Detention without Trial in Wartime Britain, Oxford u.a. 1992.

SINGER, Barnett, Lyautey. An Interpretation of the Man and the French Imperialism, in: Journal of Contemporary History 26 (1991) S. 131-157.

SLAVIN, David H., Anticolonialism and the French Left. Opposition to the Rif War 19251926, Ann Arbor (Diss.) 1982.

-, The French Left and the Rif War 1924-1925. Racism and the Limits of Internationalism, in: Journal of Contemporary History 26 (1991) S. 5-32.

SMELE, Jonathan D., Civil War in Siberia. The Anti-Bolshevik Government of Admiral Kolchak 1918-1920, Cambridge u.a. 1996.

Sources de l'histoire du Proche-Orient et de l'Afrique du Nord dans les archives et bibliothèques françaises, hg. von der Commission française du guide des sources de l'histoire 
des nations, München, London 1996 (Guides to the Sources for the History of the Nations, Ser. 3, North Africa, Asia and Oceania, 5,1).

SPECTOR, Jack J., Surrealist Art and Writing 1919-1939. The Gold of Time, Cambridge u.a. 1997.

SPENCER, William, Historical Dictionary of Morocco, Metuchen 1980 (African Historical Dictionaries, 24).

SQUIRES, Mike, Saklatvala. A Political Biography, London 1990.

STALEY, Eugene, Mannesmann Mining Interests and the Franco-German Conflict over Morocco, in: Journal of Political Economy 40 (1932) S. 52-73.

STEIN, Meyer L., Under Fire. The Story of American War Correspondents, Parsippany 1968.

STENTON, Michael, LEES, Stephen, Who's Who of British Parliament. A Biographical Dictionary of the House of Commons, Bde. 2f., London 1978.

STILLER, Hartmut, Gaskrieg, Völkerrecht, Geheimrüstung. Zur Frage der Beschränkung von bakteriologischen und chemischen Waffen in der Zwischenkriegszeit, in: Wissenschaft \& Frieden 12 (1995), H. 3, S. $40-44$.

STOCK, Raymond, The Works of Vincent Sheean. The Dust of an Honest Man, in: Journalism History 11 (1984) S. 46-50.

STOECKER, Helmuth (Hg.), Drang nach Afrika. Die deutsche koloniale Expansionspolitik und Herrschaft in Afrika von den Anfängen bis zum Verlust der Kolonien, Berlin ${ }^{2} 1991$.

-, NMSCHOWSKI, Helmut, Marokko 1898-1914, in: STOECKER (Hg.), Drang nach Afrika, S. 205-222.

Sueiro SEOANe, Susana, España en el mediterráneo. Primo de Rivera y la »cuestión marroqui« 1923-1930, Madrid 1992.

-, El mito del estratega. Primo de Rivera y la revolución del problema de Marruecos, in: Cuadernos de historia contemporánea 16 (1994) S. 113-129.

-, Contrabando en las costas del Rif. Armas europeas para Abd-el-Krim, in: RIPOLL PERELLó, LADERO QueSADA (Hg.), Actas, S. 261-269.

-, Spanish Colonialism during Primo de Rivera's Dictatorship, in: Raanan REIN (Hg.), Spain and the Mediterranean since 1898, London 1999, S. 48-64.

SUOLINNA, Kirsti, The Relationship between Edward Westermarck and Abdessalam ElBaqqali, in: Suomen antropologi 19 (1994), H. 4, S. 51-55.

-, Abdessalam El-Baqqali, informateur et ami d'Edward Westermarck, in: Temenos 31 (1995) S. 1-12.

-, Edward Westermarck's Fieldwork and Field Expeditions in Morocco, in: DIES., Catherine af HĀLLSTRÖM, Tommy LAHTINEN (Hg.), Portraying Morocco. Edward Westermarck's Fieldwork and Photographs 1898-1913, Äbo 2000, S. 7-26.

SwaRTZ, Marvin, The Union of Democratic Control in British Politics during the First World War, Oxford 1971.

TAHTAH, Mohammed, Entre pragmatisme, reformisme et modernisme. Le rôle politico-religieux des Khattabi dans le Rif (Maroc) jusqu'à 1926, Leiden (Diss.) 1995.

-, Entre pragmatisme, réformisme et modernisme. Le rôle politico-religieux des Khattabi dans le Rif (Maroc) jusqu'à 1926, Leuven 2000 (Orientalia Lovaniensia analecta, 91).

TEN, Salvador, Exploitation du gisement de minerai de fer d'Ouichane Achara de la Compagnie espagnole des mines du Rif, in: Mines et géologie 4 (1961) S. 55-61.

TERRIER, Auguste, Les »Frères de la côte« du Rif, in: Bulletin du Comité de l'Afrique française 35 (1925) S. 548-549, S. 652-657.

-, Les »Frères de la côte« du Rif, in: Bulletin du Comité de l'Afrique française 36 (1926) S. $38-45$, S. 68-71, S. 111-114, S. 176-179, S. 299-309.

-, Les »Frères de la côte« du Rif, in: Bulletin du Comité de l'Afrique française 37 (1927) S. 46f.

The History of the Times. The Twentieth Century Test 1884-1912, London 1947. 
THIERRY, René, L'agression des Rifains contre le Maroc francais, in: Bulletin du Comité de l'Afrique française 35 (1925) S. 399-411, S. 529-541, S. 596-605, S. 664-666.

ThOMAS, Nigel, The French Foreign Legion. London 1981.

TIERSKY, Ronald, French Communism 1920-1972, New York, London 1974.

TOLÉDANO, Joseph, La saga des familles. Les juifs du Maroc et leurs noms, Tel-Aviv 1983.

TOYNBEE, Arnold J., The Islamic World since the Peace Settlement, London 1927 (Survey of International Affairs 1925, 1).

TriCOU, Luc, La création de Port-Say, in: L'Afrique du Nord illustré, 20.3.1909.

TRYSTRAM, Jean-Paul, Le mineur marocain. Contribution statistique à une étude sociologique, Paris (Diss.) 1955.

TSCHFFELY, Aime F., Don Roberto. Being the Account of the Life and the Works of R.B. Cunninghame Graham 1852-1936, London 1937.

TUSELL, Javier, SAZ, Ismael, Mussolini y Primo de Rivera. Las relaciones políticas y diplomatícas de dos dictaduras mediterráneas, in: Boletín de la real academia de la historia 169 (1982) S. 413-483.

-, La dictadura de Primo de Rivera 1923-1930, in: Jover ZAMORA (Hg.), La España, S. 131-747.

ULRICH, Volker, Völkermord im Rif, in: Die Zeit, 1.2.1991.

USBORNE, Cecil V., The Conquest of Morocco, London 1936.

VaIDON, Lawdom (d.i. David WoOlMaN), Tangier. A Different Way, Metuchen, London 1977.

VALYNSEELE, Joseph, Les Say et leurs alliances. L'étonnante aventure d'une famille cévenole, Paris 1971.

VERNEAU, R., Les crânes marocains de la mission de Madame Camille du Gast, Angers 1913.

VERNIER, Bernard, La politique islamique de l'Allemagne, Paris 1939.

VIDAL, Federico S., Religious Brotherhoods in Moroccan Politics, in: Middle East Journal 4 (1950) S. 427-446.

VILLAIN, Jean, BRUN, Marcel, Fellah ohne Faruk. Eine Ägyptenreise, Berlin 1958.

VILlALOBOS, Federico, El sueño colonial. Las guerras de España en Marruecos. Barcelona 2004.

Villanova, José L., El Protectorado de España en Marruecos. Organización política y territorial, Barcelona 2004.

VIÑAS, Ángel, Franco, Hitler y el estallido de la guerra civil. Antecedentes y consecuencias, Madrid 2001.

WaDSwORTH, Marc, Comrade Sak. Shapurji Saklatvala MP. A Political Biography, Leeds 1998.

WANDLER, Reiner, Deutsch vergast, marokkanisch vergessen, in: Tageszeitung, 26.1.2002.

WASTI, S. Tanvir, Mushir Hosain Kidwai and the Ottoman Cause, in: Middle Eastern Studies 30 (1994) S. 252-261.

WeHBERG, Hans, Der XXIV. Weltfriedenskongreß zu Paris (1. bis 7. September 1925), in: Die Friedenswarte 25 (1925) S. 289-299.

WELLARD, James, The French Foreign Legion. London 1974.

WELLER, Paul-Louis, René Fonck, in: Revue des deux mondes 153 (1983) S. 533-540.

WELSCH, Otto, Das marokkanische Problem, in: Militär-Wochenblatt, 4.7.1925.

WESSEL, Horst A., Die Familie Mannesmann in Marokko 1907-1914. Ein Beispiel partnerschaftlicher Wirtschaftsentwicklung, Düsseldorf 1996.

-, Die Tochniker der Familie Mannesmann, in: Wolfhard WEBER (Hg.), Ingenieure im Ruhrgebiet, Münster 1999 (Rheinisch-westfälische Wirtschaftsbiographien, 17), S. 123-148. 
WHITE, Gavin, Firearms in Africa. An Introduction, in: Journal of African History 12 (1971) S. 173-184.

WILKENS, Andreas, Archivführer Paris 19. und 20. Jahrhundert. Zentrale Bestände zu Politik, Wirtschaft und Gesellschaft in Archiven und Bibliotheken, Sigmaringen 1997 (Instrumenta, 2).

WILLIAMSON, Francis T., Germany and Morocco before 1905, Baltimore 1937.

WILSON, Trevor, The Downfall of the Liberal Party 1914-1935, London 1968.

WINKLER, Henry R., The Emergence of a Labor Foreign Policy in Great Britain 1918-1929, in: Journal of Modern History 28 (1956) S. 247-258.

WINTGEN, Thomas, Wermelskirchen in der Weimarer Republik. Die Jahre 1918 bis 1932 im Spiegel der Lokalpresse, Wermelskirchen 1993 (Wermelskirchen, Beiträge zu unserer Geschichte, 6).

-, Menschen, Fakten, Akten 1933-1945. Auswertung der Gestapo- und Entnazifizierungsakten. Auswahl von Zeitungsberichten. Wermelskirchen 1998 (Wermelskirchen, Beiträge zu unserer Geschichte, 9).

WIRTH, Albrecht, Der Kampf um Marokko, Dachau 1925.

WIRZ, Albert, Für eine transnationale Geschichtsschreibung, in: Geschichte und Gesellschaft 27 (2001), S. 489-498.

WOHL, Robert, French Communism in the Making 1914-1924, Stanford 1966.

WOJAK, Irmtrud, MEINL, Susanne (Hg.), Völkermord und Kriegsverbrechen in der ersten Hälfte des 20. Jahrhunderts, Frankfurt a. M., New York 2004 (Jahrbuch 2004 zur Geschichte und Wirkung des Holocaust).

WOLF, Dieter, Die Doriot-Bewegung. Ein Beitrag zur Geschichte des französischen Faschismus, Stuttgart 1967 (Quellen und Darstellungen zur Zeitgeschichte, 15).

WOLF, Jean, Les secrets du Maroc espagnol. L'epopée d'Abd-el-Khaleq Torres, Casablanca 1994.

WOLGENSINGER, Jacques, André Citroën, Stuttgart 1992.

WoOlman, David S., Rebels in the Rif. Abd el Krim and the Rif Rebellion, Stanford 1968.

-, Stars in the Firmament. Tangier Characters 1660-1960, Pueblo 1998.

Youssoufl, Abderrahman, Les institutions de la République du Rif, in: Abd el-Krim et la République du Rif, S. 81-100.

ZAPPA, Paolo, Il sergente Klems, Mailand 1941.

ZIEMANN, Benjamin, Fahnenflucht im deutschen Heer 1914-1918, in: Militärgeschichtliche Mitteilungen 55 (1996) S. 93-130.

ZNIBER, Mohammed, Le rôle d'Abd el-Krim dans la lutte pour la liberation nationale dans le Maghreb, in: Abd el-Krim et la République du Rif, S. 489-503.

\subsection{Internetseiten}

ABD-EL KRM, Hébert, Guerre chimique pendant la guerre du Rif sur le satellite ALAARABIA, in: Antiweblog, 13.3.2004.

http://www.preavis.org/antiweblog/article.php3?id_article=52 [16.1.2005].

Colloque sur les armes chimiques pendant la guerre du Rif, in: Kabyle.com, 15.2.2004. http://www.kabyle.com/article.php3?id_article=8297 [16.1.2005]. 
CORREALE, Francesco, Micro-History of the Modern Maghreb. Traffickers of Weapons in Colonial Morocco. A Case Study: The »Affaire Cholvy de Tranoy \& C.« 1912-1913, in: Middle East History and Theory Workshop at The University of Chicago, 17th Middle East History and Theory Conference (May 10-11, 2002). http://cas.uchicago.edu/workshops/mehat/past_conferences/Correale.pdf [31.12.2004].

CrISS, Bilge, BILGIN, Pinar, Turkish Foreign Policy toward the Middle East, in: MERIA, Middle East Review of International Affairs 1 (1997). http://www.biu.ac.il/SOC/besa/meria/journal/1997/issuel/jvlnla3.html [10.6.2001].

DiGNAC, Véronique, JOLY, Bertrand, Historique du Journal 1892-1944, in: Archives nationales, Fonds du Journal (Sous-série 8AR), Répertoire numérique (1997). http://www.archivesnationales.culture.gouv.ff/chan/chan/fonds/EGF/AP/noticesap/AR/8\% 20AR.html [11.4.2003].

FRETrAG, Ulrike, Translokalität als ein Zugang zur Geschichte globaler Verflechtungen (3.6.2005). http://geschichte-transnational.clio-online.net/forum/id=632\&count=15\&recno=1\&type= artikel\&sort=datum\&order $=$ down\&segment= 16 [3.6.2005].

KING, Charles, Queen of the Highlanders. Edith Durham in "The Land of the Living Past«, in: Times Literary Supplement, 4.8.2000.

http://www.members.nbci.com/_XMCM/knigi_en/ed/e_durham.html [6.7.2001].

MICHALSKI, Bernadette, The Mineral Industry of Morocco and Western Sahara. http://www.minerals.usgs.gov/minerals/puts/country/9226097.pdf [7.6.2001].

PATEL, Kiran K., Transnationale Geschichte - ein neues Paradigma?

URL: http://geschichte-transnational.clio-online.net/forum/2005-02-001 [23.5.2005].

Sото, Paco, El ejército colonial español empleó armas químicas en la guerra del Rif, in: Andalucia libre $\mathrm{N}^{\circ} 223,23.2 .2004$.

http://www.elistas.net/lista/andalucialibre/archivo/indice/201/msg/258 [16.1.2005].

WENGENROTH, Ulrich, Auslandsinvestitionen der deutschen Schwerindustrie zur Sicherung ihrer Erzversorgung zwischen Gründerjahren und Weltwirtschaftskrise, Arbeitspapier, 15.11.1998 (Münchner Zentrum für Wissenschafts- und Technikgeschichte). http://www.mzwtg.mwn.de/arbeitspapiere/we_erzfdi.pdf [14.5.2003]. 